\title{
SEPUTAR PERSOALAN PELAYANAN WAKAF DI KANTOR URUSAN AGAMA (KUA) KECAMATAN KELING KABUPATEN JEPARA
}

\author{
Saekhu ${ }^{1}$
}

\begin{abstract}
Religious Affairs Office (KUA) Keling Sub-district as a facilitator of social and religious organizations officially designated by the government cannot be separated from the problems associated with land endowments. Besides Indonesian Waqf Board as the official agency of the government in charge of the waqf in Indonesia cannot be autonomous in terms of organization and management of these institutions due to lack of budget provided by the state to BWI and the lack of state budget is one of the factors of weak existing management system at BWI. This study is a descriptive kualitative analysis and includes field research (field Research). Methods of data collection using interview techniques, observation, observation and documentation, while wearing his approach and juridical and normative approach using inductive data analysis.

The results of this study that waqf ministry of Religious Affairs in the Office of the District Rivet is still a lack of human resources in the field do not affect the maximum donation that endowments services provided to the public. In general ministry of waqf in the Office of Religious Affairs does not affect the level of economic welfare of the people, this happens because of the cult and the management of waqf in District Rivet still traditional individual and yet professional. In other words endowments administrative services submitted to the Office of Religious Affairs (KUA) will Keling Sub-district, but the management and supervision of the Nazarenes submitted to the village.
\end{abstract}

Keywords: Ministry of Endowments, Economic Improvement People.

\section{Pendahuluan}

Wakaf adalah memberikan sebagian atau seluruh harta yang produktif terlepas dari campur tangan pribadi, menyalurkan hasil dan manfaatnya secara khusus sesuai dengan tujuan wakaf baik untuk kepentingan perseorangan,

${ }^{1}$ Dosen Fakultas Ekonomi dan Bisnis Islam IAIN Walisongo Semarang

Volume V/Edisi 2/Oktober 2014 
Seputar Persoalan Pelayanan Wakaf di KUA

masyarakat, agama atau umum dan pahala akan mengalir kepada siwakif.2 Menurut Abu Zahrah wakaf telah dikenal sebelum Islam walaupun dalam prakteknya belum dinamakan wakaf tetapi ini telah menunjukkan bahwa praktik tersebut sama dengan wakaf. ${ }^{3}$ Allah SWT berfirman dalam QS. Al-Hajj ayat 77 .

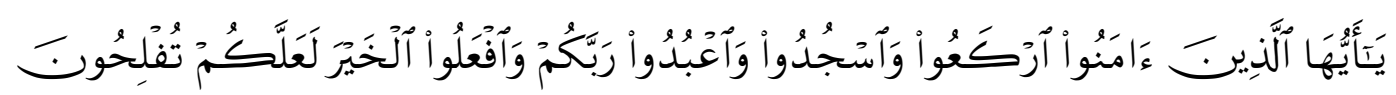

Artinya: "Hai orang-orang yang beriman, ruku'lah kamu, sujudlab kamu, sembablab Tubanmu dan berbuatlab kebajikan, supaya kamu mendapatkan kemenangan"(QS. Al Hajj: 77).4

Wakaf merupakan perbuatan memutus hubungan hukum antara pemilik dengan barang yang diwakafkan dan kemudian benda yang diwakafkan dilembagakan. artinya benda yang diwakafkan dicabut dari lalu lintas hukum dan perekonomian sebab barang yang telah diwakafkan tidak dapat diperjual belikan, dihibahkan dan diwariskan. Pada dasarnya wakaf merupakan tindakan sukarela ${ }^{5}$ dan wakaf bukan hanya seperti sedekah biasa tetapi lebih besar pahala dan manfaatnya terhadap diri siwakif itu sendiri karena pahala wakaf itu terus-menerus mengalir selama barang wakaf itu masih dimanfaatkan. ${ }^{6}$ Wakaf $^{7}$ mendapat perhatian sangat baik sehingga wakaf menjadi amal sosial yang mampu memberikan manfaat kepada masyarakat secara umum dan dalam perjalanan sejarah wakaf terus berkembang dan selalu berkembang bersamaan dengan laju perubahan zaman dengan berbagai inovasi-inovasi yang relevan. ${ }^{8}$

Menurut Peraturan Pemerintah No.28 Tahun 1977 tentang Perwakafan Tanah Milik (LN.Tahun.1977.No.28.TLN.No.3107)Peraturan

2. Mundzir Qahaf, Manajemen Wakaf Produktif, Terjemahan Muhyidin Mas Rida dan Abdurrahman Kasdi, Jakarta: Khalifa, 2004, hlm, 3.

3. Muhammad Abu Zahrah, Muhadarat Fi Al- Waqf, Mesir: Daar Al-Fikr Al- Araby, 1971, hlm, 5 . hlm, 526 .

${ }^{4}$.Departemen Agama RI, Al-Quran Dan Terjemah, Semarang, PT, Tanjung Mas Inti, 1992, hlm, 483.

5. Ahmad Rofiq, Hukum Islam di Indonesia, Jakarta: PT RajaGrafindo Persada, Cet.I, 1995,

6. Sulaiman Rasjid, Fiqh Islam, Bandung: Sinar Baru Algesindo, 1994, hlm, 341.

7. Ibid, hlm, 342

8.Departemen Agama RI, Pedoman Pengelolaan Dan Pengembangan Wakaf, Jakarta: Ditjen Bimas Islam Dan Penyelenggaraan Haji, 2004, hlm, 30. 
Pemerintah No.28 tersebut, merupakan perwujudan dari Undang-Undang No.5 Tahun 1960 tentang Undang-Undang Pokok Agraria (UUPA) pada pasal 49 ayat 3 BAB I bagian IX tentang Hak Tanah untuk Keperluan Suci dan Sosial. Dalam PP No.5 Tahun 1960 tentang Undang-Undang Pokok Agraria (UUPA), materi PP hanya mengatur tentang perwakafan tanah milik, sedang untuk perwakafan benda lainnya seperti benda bergerak belum ada pengaturannya.

Meskipun sudah ada beberapa peraturan perundang-undangan yang berkenaan dengan masalah perwakafan, kenyataan menunjukkan bahwa dilihat dari tertibnya administrasi, perwakafan di Indonesia memang meningkat karena sudah cukup banyak tanah wakaf yang bersertifikat, akan tetapi dampaknya bagi kesejahteraan sosial ekonomi masyarakat belum Nampak. ${ }^{9}$ Maka dari itu, pemerintah menyusun dan mengundangkan Undang-Undang Republik Indonesia No.41 Tahun 2004 tentang Wakaf, pada tanggal 27 0ktober 2004 oleh Presiden RI. Dengan dikeluarkannya UU No. 41/2004 tersebut maka lengkaplah sudah peraturan perundang-undangan yang mengatur tentang perwakafan di Indonesia. ${ }^{10}$

Diharapkan dengan diundangkannya UU No. 41/2004, berbagai persoalan perwakafan dapat diatasi, Jadi Dalam UU No. 41/2004, disusun harta benda wakaf berupa benda bergerak, yang meliputi uang, logam mulia, surat berharga, kendaraan hak atas kekayaan intelektual serta hak sewa. ${ }^{11}$ Dengan Undang-Undang ini diharapkan agar harta benda wakaf dapat difungsikan dan dimanfaatkan lebih proporsional. diantara bentuk harta wakaf berupa harta bergerak yang berbentuk hak ialah hak atas kekayaan intelektual dan hak sewa. ${ }^{12}$ Pelayanan wakaf dalam meningkatkan ekonomi umat merupakan bentuk wakaf baru yang perlu dikaji dan dikembangkan dalam perwakafan di Indonesia. Bentuk wakaf ini merupakan bentuk wakaf yang sangat produktif untuk memajukan kesejahteraan ekonomi masyarakat yang

\footnotetext{
9. Farida Prihatini, et al, Hukum Islam Zakat dan Wakaf Teori dan Prakteknya di Indonesia, Depok, Papas Sinanti dengan Badan Penerbit Fakultas Hukum UI, Cet-1, 2005, hlm, 130.

10. Abdul Ghofur, Hukum dan Praktik Perwakafan di Indonesia, Yogyakarta: Pilar Media, 2005, $\mathrm{hlm}, 5$.

11. Hadi Setia Tunggal, Undang-Undang RI No 41 tahun 2004 Tentang Wakaf, Jakarta: Harvarindo, 2005, hlm, 8-9.

12. Op. Cit, hlm, 6
}

Volume V/Edisi 2/Oktober 2014 
Seputar Persoalan Pelayanan Wakaf di KUA

mempunyai muatan nilai sosial dan ibadah. David Osborne dan Ted Gabler menyatakan bahwa pengembangan organisasi sebetulnya hanya bermuara pada terwujudnya a smaller, better, faster and cheaper government..$^{13}$ Salah satu fungsi Kantor Urusan Agama (KUA) Kecamatan Keling Kabupaten Jepara dalam hal ini sebagai instansi pemerintah dalam menyelenggarakan pelayanan kepada masyarakat kini semakin disorot karena Kantor Urusan Agama (KUA) Kecamatan Keling Kabupaten Jepara dalam hal ini menjadi sorotan masayarakat dalam memberikan pelayanan wakaf dalam meningkatan ekonomi umat. Revitalisasi peningkatan kualitas pelayanan publik yang diselenggarakan instansi pemerintahan kini semakin mengemukan bahkan menjadi tuntutan masyarakat. Persoalan yang sering dikritisi masyarakat atau para penerima layanan adalah persepsi terhadap "kualitas" yang melekat pada selurus aspek pelayanan.

\section{Permasalahan}

Dalam masyarakat masih banyak yang belum mengetahui secara jelas ketentuan hukum dan tata cara dan prosedur wakaf yang diselenggarakan di Kantor Urusan Agama (KUA) Kecamatan Keling Kabupaten Jepara secara lebih komprehensip pembahasan, sehingga dalam penelitian ini, maka peneliti mengadakan spesifikasi kajian yang memfokuskan pembahasan pada bentuk tingkat pelayanan wakaf dalam meningkatkan ekonomi umat.

\section{Pembahasan}

\section{Wakaf}

Kata wakaf sendiri berasal dari kata kerja waqafa (fiil madi) yaqifu (fill mudari) warfan (isim masdar) yang berarti berhenti atau berdiri.. ${ }^{14}$ Adapun menurut istilah wakaf berarti berhenti atau menahan yang dapat diambil manfaatnya tanpa musnah seketika dan untuk mendapatkan keridhaan Allah SWT. ${ }^{15}$ 1989, hlm, 11

${ }^{13}$.Davidow W, \& Uttal B. 1989. Total Customer Service. New York: Harper \& Row Publisher, 1987, hlm, 49.

14. Adijani Al-Alabij, Perwakafan Tanah Di Indonesia Teori dan Praktek, Banjarmasin, Stihsa, 1987 , hlm, 5 .

15. Ahmad Azhar Basyir, Hukum Islam Tentang Wakaf, Ijarah dan Syirkah. Jakarta: Al-Ma'arif, 
Lahirnya undang-undang nomor 5 tahun 1960 tentang Agraria telah memperkokoh eksistensi wakaf di Indonesia ${ }^{16}$ Untuk memberi kejelasan hukum tentang wakaf dan sebagai realisasi dari undang-undang ini, pemerintah telah mengeluarkan Peraturan Pemerintah Nomor 28 Tahun 1977 tentang Perwakafan Tanah Milik. Dalam PP ini dikemukakan bahwa wakaf adalah suatu lembaga keagamaan yang dapat digunakan sebagai salah satu sarana guna pengembangan kehidupan keagamaan, khususnya bagi umat yang beragama Islam dalam rangka mencapai kesejahteraan spiritual dan materiil menuju masyarakat adil dan makmur berdasarkan Pancasila. Lahirnya PP ini disebabkan karena peraturan yang lama tentang pengaturan wakaf dianggap belum memadai dan belum memenuhi kebutuhan tentang tata cara pengaturan wakaf di Indonesia.

Sejak berlakunya PP Nomor 28 Tahun1977 ini, maka semua PERPU tentang perwakafan sebelumnya, sepanjang bertentangan dengan PP ini dinyatakan tidak berlaku lagi. Sedangkan hal-hal yang belum diatur, akan diatur lebih lanjut Menteri Agama dan Menteri Dalam Negeri sesuai dengan bidang wewenang dan tugas masing-masing. Langkah-langkah yang telah diambil oleh Departemen Agama dengan tebitnya PP Nomor 28 tahun 1977 sebagai berikut ${ }^{17}$ dan Dalam penjelasan umum UU Nomor 41 Tahun 2004 tentang wakaf dijelaskan bahwa salah satu langkah stategis untuk meningkatkan kesejahteraan umum dan peran wakaf sebagai pranata ibadah sosial. ${ }^{18}$

Wakaf adalah perbuatan hukum seseorang atau kelompok orang atau badan hukum yang memisahkan sebagian dari benda miliknya dan melembagakannya untuk selama-lamanya guna kepentingan ibadat atau kerpeluan umum lainnya sesuai dengan ajaran Islam ${ }^{19}$ dan wakaf menyediakan harta benda yang dipergunakan hasilnya untuk kemaslahatan umum .20

Unsur-unsur wakaf atau rukun wakaf menurut sebagian besar dan fiqib islam telah dikenal ada enam rukun yaitu antara lain sebagai berikut: , 251-252

19. Kompilasi Hukum Islam di Indonesia, Derektorat Pembinaan Badan Peradilan Agama Islam Derektorat Jenderal Pembinaan Kelembagaan Agama Islam Departemen Agama R.I, Jakarta, 2001, hlm, 99.

20. Nasaruddin Umar. Fiqih Wakaf, (Direktorat Pemberdayaan Wakaf Direktorat Jendral Bimbingan Masyarakat Islam Departemen Agama RI. Jakarta, 2007, hlm, 21. 
Seputar Persoalan Pelayanan Wakaf di KUA

orang yang mewakafkan (Wakiff), ${ }^{21}$ Benda yang diwakafkan (Mauquf), tempat wakaf penerima wakaf (manquf 'alihi) Pernyatan/lafadz penyerahan wakaf (Sighot) /ikrar wakaf dan pengelola wakaf/Nazhir.

\section{Pelayanan Wakaf}

Kepuasan masyarakat terhadap pelayanan wakaf oleh lembaga Ketua Urusan Agama (KUA) Kecamatan Keling Kabupaten Jepara merupakan faktor utama yang harus diperhatikan oleh penyedia pelayanan publik karena kepuasan masyarakat menentukan keberhasilan pemerintah dalam menyelenggarakan pelayanan public (masyarakat). ${ }^{22}$

Kantor Urusan Agama (KUA) selaku penyedia revitalisasi pelayanan dalam memberikan pelayanan kepada publik adalah pegawai Kantor Urusan Agama (KUA) Kecamatan Keling Kabupaten Jepara yang melaksanakan tugas pelayanan publik sesuai dengan peraturan perundang-undangan yang telah diamanatkan dan penerima pelayanan publik adalah orang, masyarakat, lembaga instansi pemerintah dan dunia usaha, yang memperoleh manfaat dari suatu kegiatan penyelenggaraan pelayanan publik.Kepuasan pelayanan berdasarkan Kep./25/M.PAN/2/ 2004 yaitu hasil pendapat dan penilaian masyarakat terhadap kinerja pelayanan yang diberikan oleh aparatur penyelenggara pelayanan publik. ${ }^{23}$

Pelayanan wakaf (services) merupakan sebuah kegiatan, proses dan interaksi serta merupakan perubahan suatu kondisi pada setiap diri manusia, bahkan secara ekstrim dapat dikatakan bahwa pelayanan tidak dapat dipisahkan dari kehidupan manusia. ${ }^{24}$ Menurut Kotler pelayanan kepada masyarakat adalah setiap kegiatan yang menguntungkan baik individu atau klompok, serta menawarkan kepuasan meskipun hasilnya tidak terikat pada produk secara fisik, dengan kata lain pelayanan merupakan sebuah intraksi langsung maupun tidak langsung dan menyediakan kepuasan pada masyarakat. ${ }^{25}$

21. Ibid, hlm, 22.

22. Tjiptono, F \& Chandra, G. Service Quality \& Satisfaction. Yokyakarta, 2005, hlm, 198.

23. Kementrian Pendayagunaan Aparatur Negara. Keputusan Menteri Pendayagunaan Aparatur Negara Nomor: KEP/25/M.PAN/2/2004, Tentang Pedoman Umum Penyusunan Indeks Kepuasaan Masyarakat Unit Pelayanan Instansi Pemerintah, Jakarta, 2004.

24. Sinabembela, Reformasi Pelayanan Publik: Teori, kebijakan, dan implementasi, Jakarta: Bumi Aksara, 2010, hlm, 3.

25. Philip Kotler and Kevin Lane Keller, Marketing Management, Pearson International Edistion, 2006, hlm, 372. 


\section{Peningkatan Ekonomi Umat}

Perekonomian umat sebenarnya telah muncul pada masa Nabi Muhammad SAW masih hidup. Pada masa Nabi SAW lembaga perekonomian tersebut berbentuk Bayt al-Mal26. Pada masa Nabi SAW Ekonomi Islam sendiri merupakan sekumpulan dasar-dasar umum ekonomi yang disimpulkan dari Al-qur" an dan As-Sunnah. ${ }^{27}$

Menurut Midgley mendefinisikan kesejahteraan sosial ini diartikan sebagai "a condition or state of human well-being". Kondisi terjadi manakala kehidupan manuusia aman dan bahagia karena kebutuhan dasar akan gizi, kesehatan, pendidikan, tempat tinggal dan pendapatan dapat terpenuhi, serta manakala manusia memperoleh perlindungan dari resiko - resiko utama yang mengancam kehidupannya. ${ }^{28}$

Mohammad Suud mendefinisikan kesejahteraan di bagi menjadi tiga kelompok yaitu kesejahteraan sosial sebagai suatu keadaan, kesejahteraan sebagai suatu kegiatan atau pelayanan dan kesejahteraan sosial sebagai ilmu. ${ }^{29}$

Menurut Segel dan Bruzy (1998: 8) mengatakan bahwa kesejahteraan sosial adalah sebuah kondisi sejahtera dari suatu masyarakat meliputi kesehatan, keadaan ekonomi, kebahagiaan, dan kualitas hidup rakyat. ${ }^{30}$

Penelitian ini menggunakan metode deskriptif kualitatif, bertujuan untuk menggambarkan, meringkas berbagai kondisi, realitas sosial yang ada di masyarakat yang menjadi obyek penelitian dan berupaya menarik kepermukaan bagaimana tingkat pelayanan wakaf dalam meningkatkan ekonomi umat di Kantor Urusan Agama (KUA) Kecamatan Keling Kabupaten Jepara. Penelitian deskriptif kualitatif mempunyai sifat yang mendalam dan sesuai dengan kondisi obyek penelitian. ${ }^{31}$ sumber data primer dan teknik pengumpulan data alam penelitian ini menggunakan

2002. 20

26. Djazuli. Yanwari, Yadi. Lembaga Perekono mian Umat. Jakarta: PT. Raja GrafindoPersada.

27. Ibid, hlm, 23-24.

${ }^{28}$ Midgley, J. Globalization, Capitalism And Social Welfare: A Social Work and Globalization, 2000, hlm, 1328.

29. Suud, Mohammad, Orientasi Kesejabteraan Sosial, Jakarta: Prestasi Pustaka Publisher, 2006, hlm, 67 .

30. Op, Cit, hlm, 28.

31. Burhan Bungin, Penelitian Kualitatif, Jakarta: Kencana Prenanda Media Group, 2007, hlm, 68-69.

Volume V/Edisi 2/Oktober 2014 
teknik observasi, wawancara dan dokumentasi. ${ }^{32}$ Kantor Urusan Agama (KUA) Kecamatan Keling merupakan salah satu KUA tertua di Kabupaten Jepara. Menurut sejarah, belum diketahui secara pasti pada tahun berapakah KUA Keling didirikan. Tetapi dari data kepala KUA Keling yang ada, maka dapat diperkirakan berdirinya sekitar tahun 1920.

Kondisi geografis Kantor Urusan Agama (KUA) Kecamatan Keling beralamat di Jalan Raya Jepara - Kelet KM. 36 dukuh Sambungoyot desa Kelet Kecamatan Keling Kabupaten Jepara Kecamatan Keling merupakan satu dari eman belas kecamatan yang ada di wilayah Kabupaten Jepara, sebelah barat berbatasan dengan Kecamatan Kembang, sebelah timur berbatasan dengan Kecamatan Cluwak Kabupaten Pati, sebelah utara berbatasan dengan Kecamatan Donorojo, sebelah selatan berbatasan dengan Kecamatan Gebog Kabupaten Kudus. ${ }^{33}$

Pelayanan wakaf merupakan sebuah unsur yang mengandung unsur investasi masa depan dan mengembangkan wakaf produktif untuk masa yang akan datang sesuai dengan tujuan wakaf sehingga wakif harus menerima pelayanan yang baik, dengan demikian KUA Kecamatan Keling selaku lembaga sudah seharusnya melayani masyarakat dengan sepenuh hati. Sehingga tidak terkesan bahwa pelayanan wakaf yang diberikan di KUA Kecamatan Keling sulit dan rumit bahkan berbelit-belit, masyarakat (si wakif) dibiarkan menunggu terlalu lama menunggu bahkan pelayanan yang diberikan membosankan.

Kualitas pelayanan wakaf di KUA kecamatan keling selama ini dapat dikatakan kurang memuaskan dikarenakan ada kesenjangan anatara harapan masyarakat sebagai pengguna layanan/ekpektasi dan nilai yang diterima masayarakat terhadap pelayanan tidak ada kesesuaian atau tidak seimbang. Dari kelima harapan indikator kualitas pelayanan wakaf menurut teori yang peneliti gunakan semua nilai ekpektasi masyarakat lebih besar dari pada persepsi masyarakat iru sendiri sehingga terjadi gap/ jarak antara keduanya. Sehingga kualitas pelayanan wakaf tidak memberikan sumbangan yang bermanfaat ditengah-tengah masyarakat.

Pelayanan wakaf di zaman modern diberikan melalui berbagai bentuk yang bermacam-macam diantaranya tanah wakaf yang bergerak atau tanah yang tidak bergekak, investasi berupa pembangunan ruko, hlm, 225.

32. Sugiyono, Metodologi Penelitian Kuantitatif Kualitatif dan R $\mho D$, Bandung: Alfabeta, 2011,

33. Anggaran Dasar \& Anggaran Rumah Tangga Kantor Agama Kecamatan (KUA) Kecamatan Keling Kabupaten Jepara, Jepara, 2010, hal, 4-6. 
kepemilikan saham, sehingga hasil pengembangan wakaf yang diberikan akan dengan mudah untuk dirancang baik dari sisi keuntungan atau pembangunan ekonomi dimasa yang akan datang.

Kantor Urusan Agama (KUA) Kecamatan Keling Kabupaten Jepara dalam hal ini selaku lembaga wakil dari pemerintah memberikan pelayanan kepada masyakat sudah seharusnya memiliki tekad yang kuat dalam hati untuk senantiasa memberikan bimbingan dan penyuluhan yang terbaik bagi masyarakat. Dengan memberikan pelayanan wakaf yang terbaik kepada masyarakat akan meberikan tingkat kepuasan tersendiri dihati masyarakat sehingga dengan terciptanya pelayan KUA yang baik akan menarik para pewakif lain untuk mewakafkan harta benda di jalan Allah.

Wakaf merupakan sebuah lembaga yang memiliki peran strategis dalam meningkatkan ekonomi sosial islam yang potensinya belum sepenuhnya digali dan dikembangkan. Tetapi akhir-akhir ini upaya untuk mengembangkan potensi wakaf terus menerus khususnya dalam bidang peningkatan kesejahteraan umat.

Mengenai kreteria seorang nazir wakaf seharusnya mampu memahami lima fungsi manajemen yaitu merancang, mengorganisir, mengkoordinir, memerintah, dan mengendaliakan. Dalam lima fungsi manajemen tersebut ada dua fungsi yang menjadi penunjang dalam pengelolaan wakaf yang menurut penulis belum diperhatiakan:

Perencanaan (planning) adalah memikirkan apa yang akan dikerjakan dengan sumber daya yang dimiliki. Disini seharusnya antara nazir dan Badan Wakaf Indonesia (BWI) secara bersama-sama dalam memaksimalkan pengelolaan tanah wakaf yang ada di KUA Kecamatan Keling Kabupaten Jepara sehingga benar-benar wakaf dapat produktif dan bernilai ekonomis serta dapat meningkatkan kesejahteraan ekonomi umat dalam hal ini masyarakat di Kecamatan Keling Kabupaten Jepara.

Pengorganisasian (Organizing) dilakukan dengan tujuan membagi kewenangan dalam hal ini tugas/kegiatan dengan sekala yang lebih kecil, sehingga apa yang diharapkan oleh organisasi dapat tercapai dengan lebih efektif dan efesien. Hal ini penting dimana pengorganisasian memiliki pran yang strategis dalam mengembangkan sumber daya insani, dengan kata lain yang berpran adalah BWI dapat menjadi balance terhadap peningkatan kinerja nazir sehingga nazir dapat menjalankan amanah dalam melaksanakan tugasanya dengan baik dan profesional. Artinya wakaf akan memberikan 
Seputar Persoalan Pelayanan Wakaf di KUA

dampak positif dan signifikan terhadap peningkatan kesejahteraan ekonomi umat Islam.

Berdasarkan analisis diatas menurut peneliti yang menjadi faktor pengahambat perkembangan perwakafan di indonesia adalah faktor lembaga Badan Wakaf Indonesia (BWI) yang belum memiliki kantor cabang baik di tingkat provinsi atau bahkan pada tingkat kabupaten. Selain itu BWI harus berperan akatif bekerjasama dengan nazir untuk mewujudkan mencapai kemajuan yang dicitaa-cita bersama karena Badan Wakaf Indonesia selama ini masih belum maksimal dalam memberikan pelayanan kepada masyarakat sehingga Badan Wakaf Indonesia masih di pandang sebelah mata oleh masyarakat indonesia ini terbukti masih lemahnya pengelolaan dan pengembangan wakaf yang berbasis pada kesejahteraan masyarakat.

Selain itu seharusnya Badan Wakaf Indonesia selaku lembaga yang mewakili negara mempunyai kewenangan yang sangat strategis sebagai mana amat Undang-Undang Dasr 1945 dalam membangaun dan mencerdaskan bangsa serta mengentaskan kemiskinan di Indonesia. Dengan kata lain BWI selaku lembaga wakil pemerintah sudah seharusnya melakukan pengawasan dan meminta laporan perkembangan pengelolaan wakaf secara periodik kepada para nazir dengan harapan pemantauan pengelolaan wakaf dari tahun ke tahun dapat di pantau perkembangan baik sehingga peningkatan pelayanan wakaf kepada masyarakat akan semakin baik dan hasilnya dapat digunakan untuk kemajuan masyarakat khususnya umat islam.

Secara umum wakaf produktif yang dikelola di KUA Kecamatan Keling Kabupaten Jepara belum bisa memberikan sumbangan yang signifikan terhadap peningkatan kesejahteran pada masyarakat, karena kenyataanya terbukti bahwa pelayanan wakaf di KUA Agustus 2014 tercatat sebanyak 425 tempat (luas tanah 253.287 M2), dari sekian banyak fungsi/kegunaan wakaf masih didominasi peruntukannya untuk mushola 162 tempat (luas tanah $50.128 \mathrm{~m} 2$ ), madrasah/sekolah 109 tempat (luas tanah 86.855m2), masjid 105 tempat (luas tanah 65.402m2), tanah wakaf produktif 25 tempat (luas tanah $24.166 \mathrm{~m} 2$ ), panti sosial 17 tempat (luas tanah 8.197m2), makam 4 tempat (luas tanah $13.627 \mathrm{~m} 2$ ), dan pondok pesantern 3 tempat (Luas tanah 4.912m2). artinya dengan pengelolaan wakaf produktif yang kecil ini menjadi minimum pemasukan dana wakaf yang dihasilkan. Sehingga dari banyaknya wakaf tanah yang tidak produktif ini dan kecilnya penghasilan tanah wakaf yang ini menuntut seorang nazir 
untuk harus memiliki enovasi kreatifitas dalam mengembangkan tanah wakaf tidak produktif menjadi tanah wakaf yang memiliki hasil dan berdaya guna dan bermanfaat untuk kemaslahatan umat, seperti halnya yang dilakukan oleh ta'mir masjid Al Taqwa Desa Kelet Kecamatan Keling Kabupaten Jepara dimana menerima tanah wakaf 3 (tiga) tempat (9150m2) tanah wakaf tersebut tidak produktif karena tanah berbentuk tanah tegalan, tanah wakaf tegalan tersebut adalah: (1). Sebidang tanah ukuran $4000 \mathrm{~m} 2$ terletak di Desa Kelet (2). Tanah seluas $2150 \mathrm{~m} 2$ di Desa Belingoh berupa sawah, (3). dan tanah seluas $3000 \mathrm{~m} 2$ adalah tanah tegalan. Dengan keberdaan tanah wakaf tegalan ini dikelola seorang nazir (dalam hal ini Ta'mir Masjid) sebidang sawah disewakan sebesar Rp. 7.500.000-, dan dua bidang tanah seluas $7000 \mathrm{~m} 2$ di tanami pohon sengon (dengan masa 5 tahun) dengan harga Rp. 125.000.000,-. Dengan sistem diatas maka tanah wakaf yang tidak produktif selama ini akan menjadi banyak manfaat dan memiliki hasil sehingga tanah wakaf akan menjadi mengalami perkembangan yang lebih baik untuk kemajuan umat islam dan dapat digunakan untuk menyokong ekonomi umat yang lebih baik. ${ }^{34}$

Dengan keberadaan pengelolaan tanah wakaf yang baik oleh ta'mir Masjid Al Taqwa maka kekayaan/asset masjid menjadi lebih besar diantaranya masjid Al Taqwa tidak hanya memiliki asset tanah saja tetapi kekayaan masjid bertambah diantaranya asset masjid Al Taqwa Kelet memiliki Toko dan Ruko yang dikelola secara profesional, selain itu Masjid Al Taqwa setiap bulan mampu memberikan bantuan beasiswa bagi anak yatim dan warga lingkungan masjid yang kurang manpu di lingkungan masjid.

\section{Kesimpulan}

Berdasarkan pada analisis data yang telah dilakukan, maka diperoleh kesimpulan bahwa: Pelayanan wakaf di KUA Kecamatan Keling Kabupaten Jepara belum optimalisasi sehingga pelayanan wakaf kurang berjalan dengan baik yaitu karena kurang Sumber Daya Manusia dalam bidang perwakafan. Pelayanan wakaf di KUA Kecamatan Keling Kabupaten Jepara belum bisa optimal sehingga peningkatkan ekonomi umat dilingkungan KUA Kecamatan Keling tidak memberikan dampak yang signifikan dalam mengentaskan kemiskinan.

34. Wawancara dengan Ketua Bidang Perwakafan Kantor Urusan Agama (KUA) Kecamatan Keling Kabupaten Jepara, pada tanggal 6 agustus 2014.

Volume V/Edisi 2/Oktober 2014 


\section{Saran Penelitian}

Kepada Kepala Kantor Urusan Agama (KUA) Kecamatan Keling Kabupaten Jepara dalam rangka mewujudkan keberhasilan pengelolaan wakaf, nadzir mempunyai posisi yang penting karena ditangan mereka wakaf akan berkembang atau tidak. Untuk itu agar wakaf dapat memberikan manfaat dan peningkatan kesejahteraan umat diperlukan nadzir yang memiliki wawasan luas, mampu dan cakap dan profesional serta amanah dan kepengurusannya memiliki masa bakti.

Kantor Urusan Agama (KUA) Kecamatan Keling Kabupaten Jepara dalam hal pemanfaatan harta wakaf selain untuk kepentingan sosial keagamaan, perlu dipikirkan juga upaya pemberdayaan wakaf yang berbasiskan kepada peningkatan kesejahteraan ekonomi umat yang memiliki nilai manfaat ekonomis dan bermanfaat untuk pengentasan kemiskinan dalam jangka panjang dan masyarakat sekitar perlu dilibatkan untuk ikut untuk mengawasi serta mengontrol pengelolaan dan pengembangan benda wakaf produktif, baik pada tingkat administratif maupun keuangan karena pengawasan dari masyarakat lebih efektif karena bersifat lokal.

Untuk mendukung terlaksananya pengelolaan dan pemanfaatan perwakafan yang efektif, efesien dan profesional, maka kepala Kantor Urusan Agama (KUA) Kecamatan Keling Kabupaten Jepara dalam menjalankan peran fungsinya perlu mendesak pemerintah untuk merealisasikan Badan Wakaf Indonesia sebagai lembaga otonom yang berdiri sendiri dari tingkat pusat, tingkat provinsi dan tingkat kabupaten. Dengan demikian harapannya dengan terbentuknya lembaga yang otonom yang menangani persoalan dan mengoptimalkan perwakafan secara profesional di indonesia sehingga kesejahteran ekonomi umat dari wakaf dapat dijalankan dengan lebih baik.

Perlu adanya hubungan sinergis harmonis antar pegawai Kantor Urusan Agama (KUA) Kecamatan Keling dengan para nadzir serta melaporkan perkembangan dan pengelolaannya secara priodik, sehingga dengan demikian wakaf akan mengetahui perkembangan lebih baik dan perkembangan perjalanan wakaf akan lebih dinamis. 


\section{DAFTAR PUSTAKA}

Abdul, Manan. Aneka Masalab Hukum Perdata Islam di Indonesia. Kencana, Jakarta, 2006.

Adijani Al-Alabij. Perwakafan Tanah Di Indonesia Dan Teori Dan Praktek. Banjarmasin: Stihsa. 1987.

Abdoeranet. Al-Quran Dan Ilmu Hukum Studi Perbandingan. Jakarta: Badan Bintang. 1986.

Ahmad Azhar Basyir. Hukum Islam Tentang Wakaf, Ijarah dan Syirkah. Jakarta: Al-Ma'arif. 1987.

Abidin, Zaenal. Analisis Pengarub Keandalan dan Etos Kerja Terhadap Pelayanan Publik Pegawai Kantor Pajak Pratama Medan Kota. Medan: Tesis Universitas Sumatra Utara. 2010

Ahmad, Rofiq. Hukum Islam di Indonesia. Jakarta: PT RajaGrafindo Persada, Cet.I, 1995.

Abdul, Ghofur. Hukum dan Praktik Perwakafan di Indonesia. Yogyakarta: Pilar Media. 2005.

Burhan Bungin. Penelitian Kualitatif. Jakarta: Kencana Prenanda Media Group. 2007

Barata, Atep Adya. Dasar-Dasar Pelayanan Prima. Jakarta: PT Alex Media Komputindo. 2003.

Davis, Keith. \& Newstrom, JW. Prilaku dalam Organisasi. Terjemahan. Agus Dharma. Jakarta: Erlangga. 1996.

Departemen Agama, 2007. Paradigma Baru Wakaf di Indonesia. Jakarta: Direktorat Pemberdayaan Wakaf Direktorat Jendral Bimbingan Masyarakat Islam Departemen Agama RI.

Djazuli, Yanwari, Yadi. Lembaga Perekonomian Umat. Jakarta: PT. Raja GrafindoPersada. 2002. 20 Keputusan Menteri Negara Pendayagunaan Aparatur Negara (MENPAN) Nomor. 81 Tahun 1993. 
Seputar Persoalan Pelayanan Wakaf di KUA

Elsi Kartika Sari. Pengantar Hukum Zakat dan Wakaf. Jakarta: Gramedia widiasarana Indonesia. 2006.

Departemen Agama RI. Al-Quran Dan Terjemah. Semarang: PT. Tanjung Mas Inti. 1992.

Departemen Agama RI. Pedoman Pengelolaan Dan Pengembangan Wakaf. Jakarta: Ditjen Bimas Islam Dan Penyelenggaraan Haji, 2004

Farida Prihatini. et al. Hukum Islam Zakat dan Wakaf Teori dan Prakteknya di Indonesia. Depok: Papas Sinanti dengan Badan Penerbit Fakultas Hukum UI, Cet-1. 2005.

Gronroos, C. 1992. Service Management and Marketing. Lexington Books. Massachusetts, Toronto.

Hadi Setia Tunggal. Undang-Undang RI No 41 tabun 2004 Tentang Wakaf. Jakarta: Harvarindo. 2005.

Harian Republika tanggal 4 maret 2010.

Hadiratush, Solihah. Penerapan Konsep Maslahah Mursalab dalam Wakaf . Tinjauan Terbadap Undang-Undang No. 41 Tabun 2004 Tentang Wakaf. Jakarta: Universitas Islam Negeri Syarif Hidayatullah Fakultas Syariah. 2010

Ikhwan, Abidin Basri. Islam dan Pembngunan Ekonomi. Jakarta: Gema Insani Press 2005.

Keputusan Menteri Negara Pendayagunaan Aparatur Negara (MENPAN) Nomor. 81 Tahun 1993.

Keputusan MANPAN Nomor. 63.Tahun Tentang Standar Pelayanan Publik. 2004.

KEMENPAN No. 63 Tahun 2003. Tentang Pedoman Umum Penyelenggaraan Pelayanan Publik. 2003

Kompilasi Hukum Islam di Indonesia, Derektorat Pembinaan Badan Peradilan Agama Islam Derektorat Jenderal Pembinaan Kelembagaan Agama Islam Departemen Agama R.I. Jakarta. 2001. 
Mundzir, Qahaf. Manajemen Wakaf Produktif. Terjemahan Muhyidin Mas Rida dan Abdurrahman Kasdi. Jakarta: Khalifa. 2004.

Muhammad Abu Zahrah. Muhadarat Fi Al- Waqf. Mesir: Daar Al-Fikr AlAraby. 1971.

Midgley, J. Globalization, Capitalism And Social Welfare: A Social Work and Globalization. 2000.

Nasaruddin Umar. Fiqih Wakaf. (Direktorat Pemberdayaan Wakaf Direktorat Jendral Bimbingan Masyarakat Islam Departemen Agama RI. Jakarta, 2007.

Philip Kotler and Kevin Lane Keller. Marketing Management. Pearson International Edistion. 2006.

Suhrawardi. Hukum Ekonomi Islam. Jakarta: Sinar Grafika. 2004.

Sabiq, Sayyid. Fikih Sunnah jilid XIV. Bandung: PT Alma’arif. 1987.

Sinabembela. Reformasi Pelayanan Publik: Teori, kebijakan, dan implementasi. Jakarta: Bumi Aksara: 2010.

Sinabela. Pelayanan Publik: Teori, kebijakan, dan implementasi. Jakarta: Bumi Aksara: 2010.

Suhrawardi. K. Lubis. Wakaf dan Pemberdayaan Umat. Sinar Grafika dengan UMSU Publisher. 2010.

Suud, Mohammad. Orientasi Kesejahteraan Sosial. Jakarta: Prestasi Pustaka Publisher, 2006.

Sulaiman Rasjid. Figh Islam. Bandung: Sinar Baru Algesindo. 1994.

Suharsini Arikunto. Prosedur Penelitian Suatu Pendekatan Praktik. Jakarta: Renika Cipta. 2010.

Sugiyono. Metodologi Penelitian Kuantitatif Kualitatif dan R $\ll D$. Bandung: Alfabeta, 2011.

Tanzeh, Ahmad. Pengantar Metode Penelitian. Yogyakarta: Teras. 2009.

Tjiptono, F \& Chandra, G. Service, Quality \& Satisfaction. Yokyakarta, 2005 
Seputar Persoalan Pelayanan Wakaf di KUA

Umransyah Alie. Diktat Tentang Hibah, Wasiat Dan Wakaf. Banjarmasin: Stihsa. 1987.

Undang-Undang No.41 Tahun 2004 Tentang Wakaf Tahun. 2004. 